\title{
The Digital Citizenship and Its Role in Facing \\ Electronic Terrorism among Secondary School Students in Middle East: Jordan as an Example
}

\author{
Mustafa Jwaifell \\ Curriculum and Instruction Department \\ Al-Hussein Bin Talal University \\ Ma'an, Jordan \\ E-mail: jwaifell@ahu.edu.jo \\ Sami F. Aljazi \\ Curriculum and Instruction Department \\ Al-Hussein Bin Talal University \\ Ma'an, Jordan \\ E-mail: samialjazi@ymail.com
}

\begin{abstract}
Al-Mothana Gasaymeh (Corresponding author)
Curriculum and Instruction Department

Al-Hussein Bin Talal University

Ma'an, Jordan

E-mail: Almothana.m.Gasaymeh@ahu.edu.jo
\end{abstract}

Received: November 4, 2018 Accepted: January 23, 2019 Published: February 19, 2019

doi:10.5296/ijld.v9i1.13855 URL: https://doi.org/10.5296/ijld.v9i1.13855

\begin{abstract}
The aim of the study was to determine the level of digital citizenship among secondary school students in Middle East through recruiting students from Southern of Jordan, particularly from
\end{abstract}


Ma'an Directorate to participate in the study, In addition, the study aimed to examine the relationship between students' level of digital citizenship and their attitudes toward different forms of electronic terrorism. The study sample consisted of 186 school students. The data collection tool was a questionnaire instrument. The results showed that the students had a high level of digital citizenship and their level of digital citizenship was not affected by their gender or their type of the study. In addition, the results showed that the students expressed very unfavorable attitudes toward electronic terrorism. Furthermore, the results showed that there was significant relation between students' level of digital citizenship and their attitude toward electronic terrorism. Based on the results, the study suggested that to face electronic terrorism among school students, there is need to enhance their level of digital citizenship through providing continues training and meetings that aim to make school students aware of the requirements of digital citizenship.

Keywords: Digital citizenship, electronic terrorism, Jordan, Middle East, secondary school

\section{Introduction}

The technological advancements have influenced the different aspects of our live as individuals. These technological advancements have affected the functions of the national institutions and organizations. Technologies have changed our lives and the ways of doing things.

Such advancements caused the appearance of new concepts in different fields that rely on information and communication technologies. Examples of these concepts include "digital education", "digital university", "digital commerce", "digital entertainment", "and digital arts" and so on. The technological advancements have created a virtual world that is comparable to the real one.

The new generations are marked as "Net Generations" who were characterized by eight norms that include: Freedom, customization, scrutiny, integrity, collaboration, entertainment, speed" and innovation" (Tapscott, 2009). The national education for these new generations has faced new challenges related to the use digital technologies among them. The aim of the citizenship education go beyond teaching young people knowledge and skills that make them able to participate efficiently and reliably in civic life, where citizenship education in the era of technology should also teach young people how to be digital citizen who is familiar with what is correct and incorrect, show intellectual technology performance, and take excellent decisions when using technology. The technological advancements contributed in the emergence of what is known as "digital citizenship" in the national education filed.

The relationships among individuals and countries have been affected by the digital technologies. For instance, some people have employed the digital technologies to fright other people and some countries employed the digital technologies to spread violence. The technological advancements contributed in the emergence of what is known as "electronic terrorism" in the political and relations filed. A proposed way to encounter the increasing electronic terrorism among young people is to improve their digital citizenship.

The great majority of research that discusses digital citizenship and terrorism come from the 
western world. However, the political and economical environments of the countries in the Middle East have some unique characteristics in terms of high youth population, economic hardships, lack of real democracy, and limited access to wide variety of technology. Therefore, understanding youths' perceptions of digital citizenship and terrorism would be crucial to avoid their involvements in illegal or unethical behaviors in the real or digital world.

\section{Digital Citizenship}

Digital citizenship can be defined as "the norms of appropriate, responsible behavior with regard to technology use" (Oxley, 2010, p.1). Ribble, Bailey, and Ross (2004) reported nine general aspects of behavior that reflect digital citizenship:

1. Etiquette: electronic standards of conduct or procedure; 2. Communication: electronic exchange of information; 3. Education: the process of teaching and learning about technology and the use of technology; 4. Access: full electronic participation in society; 5. Commerce: electronic buying and selling of goods; 6 . Responsibility: electronic responsibility for actions and deeds; 7. Rights: those freedoms extended to everyone in a digital world 8. Safety: physical well-being in a digital technology world 9. Security (self-protection): electronic precautions to guarantee safety (p. 7).

The need to study digital citizenship among young people is driven by several factors that include the wide spread of technology among adolescents, the emergence of World Wide Web websites that allow users to generate contents such as Web 2.0 technologies. Examples of Web 2.0 technologies include social networking sites, social media sites, and video sharing sites. Research studies have found that smartphones and Web 2.0 technologies are very popular among young students (Jwaifell, Al-Shalabi, Andraws, Awajan, \& Alrabea, 2013; Gasaymeh,Al-Taweel, Al-Moghrabi, \& Al-Ghonmein, 2017; Gasaymeh, 2018). Web 2.0 technologies allowed intent users to participants in publishing and sharing different forms of media such as Text, audio, video, and animation rather than being only inactive receivers (Murugesan, 2007).

Research studies have examined students' level of following digital citizenship standards in order to understand and diagnose their behaviors and to design and develop the appropriate interventions to modify their behaviors in case they needed. Nordin, et al, (2016) examined university undergraduate students' perceptions of their practice of five main digital citizenship norms, i.e., etiquette, commerce, responsibility, safety, and security. For the purpose of the study, 391 students completed a questionnaire. The results showed that the students had positive and moderate perceptions of their use of five main digital citizenship norms. In another study, Xu, Yang, MacLeod, and Zhu, (2018) conducted a study that aimed to examine college students' perceptions of their practice of digital citizenship norms and the potential factors that might influence their practice of digital citizenship norms. For the purpose of the study, 746 students completed a questionnaire. The results showed that the participants believed that practice digital citizenship at high level $(M=3.71, S D=0.54)$, where the participants believed that they practice the different dimensions of digital citizenship at high level, these dimensions include: respect yourself/respect others, educate yourself/connect with others, and protect yourself/protect others. In addition, the results showed that some factors related to social media 
competence i.e., social media self-efficacy, social media experience, performance expectancy, effort expectancy and facilitating conditions would influence the different dimensions of digital citizenship.

\section{Electronic Terrorism}

Electronic terrorism was used interchangeably with cyber terrorism. The literature has shown different definitions for such terms. For instance, Pollitt, (1998) proposed a definition of cyber terrorism as "the premeditated, politically motivated attack against information, computer systems, computer programs, and data which result in violence against noncombatant targets by sub national groups or clandestine agents" (p.9). Such definition was adopted from the United States Department of State's definition of terrorism and the definition of cyberspace.

Atia, (2014) defined electronic terrorism as any material or moral aggression, intimidation or threat that took place using electronic means issued by states, groups or individuals on human, body, religion, mind, or money. Atia, (2014) summarized different forms and purposes of electronic terrorism. These purposes include, first, to spread fear and terror among different people, nations and peoples; second, to violate of public order, information security, and insecurity; third, to endanger the safety and security of society; fourth, to damage and destruction of basic information infrastructure and damage to communications and information technology; fifth, to threat and blackmail of public authorities and international organizations; sixth, to revenge against the litigants; seventh, to advertise, to attract attention, and to stimulate public opinion; eighth, to collect and seize funds; ninth, to facilitate communication among terrorists; tenth, to mobilize and recruit new terrorists; eleventh, to give instructions and to spread terrorist education; twelfth, to facilitate planning and coordination among terrorists; thirteenth, to collect money. The authors of the current study believe that electronic terrorism can be defined as any electronic behavior that intended to harm others.

The appearance of social media and web 2.0 technologies; such as YouTube, WhatsApp, Line, Twitter, Facebook, Instagram, wiki, and other social media outlets; facilitate the spread of ideas by regular internet users. However, great majority of terrorist activities took place on these types of media. Terrorists can use these tools without revealing their identities and they can post different form of media to attract other people to participate in real life and electronic terrorism.

Muslim countries have been wrongfully marked as sources for traditional and electronic terrorism. However, the mass of people in Muslim countries were not supporter of terrorism. For instance, Abdullah, Sukma, and Musa, (2012) examined Malaysian Muslim people perceptions of terrorism. The study used cross-sectional survey design in which 1,200 Malaysian citizens completed a questionnaire. The results showed that the great majority of the participants did not support terrorism as a means to resolve a disagreement or to accomplish a purpose. Al-Sanad (na) showed that the Islamic religion is against all form of electronic terrorism. For instance, in relation to the invading the privacy of individual as a form of electronic terrorism, the Quran said in Surah Al-Hujurat 12:

(49:12) O you who have believed, avoid much [negative] assumption. Indeed, some 
assumption is sin. And do not spy or backbite each other. Would one of you like to eat the flesh of his brother when dead? You would detest it. And fear Allah; indeed, Allah is Accepting of repentance and Merciful.

In addition, the Islam asked Muslims to call for good, the Quran said in Surah Al-Imran:

(3:104) And let there be [arising] from you a nation inviting to [all that is] good, enjoining what is right and forbidding what is wrong, and those will be the successful.

Furthermore, the Islam forbid assault without cause, the Quran said in Surah Al-Baqarah 190 :

(2:190) Fight in the way of Allah those who fight you but do not transgress. Indeed. Allah does not like transgressors.

Another form of electronic violence that is common among school students is cyber bullying than can be defined as "an aggressive, intentional act carried out by a group or individual, using electronic forms of contact, repeatedly and over time against a victim who cannot easily defend him or herself "( Smith, et al 2008, p.376). Simply, cyber bullying can be defined as bullying by means of electronic communication tools.

Smith, et al (2008) examined cyber bullying among students between the ages of 11 and 16 years old in group of schools in the United Kingdom. Six hundred and twenty five students completed a survey in two studies. The results showed that phone call, text message, and instant messaging bullying were most common among participants. Li (2006) examined the character and the degree of school students' experience of cyber bullying. Two hundred and sixty four students from three Canadian schools completed a questionnaire. The results showed that about quarter of the participants were cyber bully victims. The percentage of male cyber bullies was higher than female cyber bullies.

Al-Said (2017) conducted a study under the title "digital citizenship and its role in the face of cyber terrorism" that argued that one way to face electronic terrorism and bullying is to enhance students' level of digital citizenship. The current study aimed to understand middle school students' perceptions and behaviors in relation to digital citizenship and all forms of electronic terrorism.

\section{Statement of the Problem}

This study was conducted under the claim that high digital citizenship will have a great role to play in standing against electronic terrorism. Therefore, the purpose of the study was to examine the level of digital citizenship among secondary school students in Southern of Jordan, particularly in Ma'an Directorate, and its relationship with their electronic terrorism. The research questions of the current study were:

Q1. What is the digital citizenship level of Ma'an secondary school students?

Q2. Do males and females of secondary school students in Ma'an Directorate differ on their level of digital citizenship and its domains?

Q3. Do secondary school students in Ma'an Directorate differ on their level of digital 


\section{Macrothink}

International Journal of Learning and Development

ISSN 2164-4063 2019, Vol. 9, No. 1

citizenship and its domains according to their type of study i.e., science, art, vocational?

Q4. What are the Ma'an secondary school students' attitudes toward electronic terrorism?

Q5. Is there a relationship between digital citizenship and attitudes toward electronic terrorism among secondary school students?

\section{Research Methodology}

The design of the study is a descriptive study, thus the researchers a cross-sectional questionnaire as a mean of collecting data on the Ma'an secondary school students' level of digital citizenship and their attitudes toward electronic terrorism.

\subsection{The Study population and Sample}

The population of the study consisted of all secondary school students in Ma'an Directorate, while the sample of the study consisted of $20 \%$ of the population. A total of 192 questionnaires were distributed to the study sample. Only 186 questionnaires were returned or were valid to be analyzed. Table 1 shows the characteristics of the participants.

Table 1. The characteristics of the sample of the study

\begin{tabular}{llll}
\hline \multirow{2}{*}{ Type of the study } & \multicolumn{2}{l}{ Gender } & Total \\
\cline { 2 - 3 } & Male & Female & 70 \\
\hline Science & 20 & 50 & 68 \\
Art & 29 & 39 & 48 \\
Vocational & 34 & 14 & 186 \\
Total & 83 & 103 & \\
\hline
\end{tabular}

The researchers' main concern committed to measure the digital citizenship and its relationship to electronic terrorism in order to understand the whole picture of students' electronic behaviors in order to give recommendations to the administration of Ministry of Education in Jordan, teachers and universities in relation to the use of internet.

\subsection{Data Collection Tool}

The study developed and modified the items of two scales:

First: digital citizenship scale was primarily drawn from Nordin and his colleagues (Nordin, et al 2016) which have been based on Ribble work and his colleagues (Ribble, Baily, \& Ross, 2004; Ribble, 2011) cited in Nordin etl, (2016). One item has been dropped according to reviewers' recommendation, where the digital citizenship scale consisted of 16 items.

Second: attitudes toward terrorism scale was primarily drawn from extensive literature review of studies exposed attitudes, aptitudes and point of views, specially the work of Abdullah, Sukma, Jamhari \& Musa (2012).

The questionnaire was validated by six reviewers who were working at a university in Jordan and they hold doctorate degrees in different academic fields in education. The Reliability of the 


\section{Macrothink}

International Journal of Learning and Development

ISSN 2164-4063

2019, Vol. 9, No. 1

questionnaire was calculated using Cronbach's Alpha Coefficients for measurement tools and their domains. In addition, Pearson correlation coefficients were calculated to measure the association between each domain in the digital citizenship and the whole scale as shown in Table 2.

Table 2. The reliability of the used instrument

\begin{tabular}{lllll}
\hline Instruments & Domain & N of items & Cronbach's Alpha & Pearson correlation \\
\hline Digital Citizenship & Etiquette & 3 & 0.380 & $0.549^{* *}$ \\
& Responsibility & 4 & 0.519 & $0.806^{* *}$ \\
& Wellbeing/Health & 3 & 0.606 & $0.644^{* *}$ \\
& Commerce & 3 & 0.538 & $0.693^{* *}$ \\
& Security & 3 & 0.613 & $0.739^{* *}$ \\
Total of Digital Citizenship & 16 & 0.780 & \\
Electronic Terrorism & 14 & 0.621 & \\
\hline
\end{tabular}

** Correlation is significant at the 0.01 level (2-tailed).

Students responses to the questionnaire' scales were transformed into five levels of digital citizenship and attitudes toward terrorism as shown in Table 3.

Table 3. Scaling digital citizenship/ attitudes toward terrorism levels

\begin{tabular}{|c|c|c|c|c|}
\hline Strongly don't agree & Don't agree & Neutral & Agree & Strongly agree \\
\hline 1 & 2 & 3 & 4 & 5 \\
\hline $1-1.80$ & $1.81-2.60$ & $2.61-3.40$ & $3.41-4.20$ & $4.21-5$ \\
\hline \multirow{2}{*}{$\begin{array}{l}\text { Very low } \\
\text { digital citizenship level/ }\end{array}$} & \multirow{3}{*}{$\begin{array}{l}\text { low } \\
\text { digital citizenship } \\
\text { level/ }\end{array}$} & \multirow{3}{*}{$\begin{array}{l}\text { Medium } \\
\text { digital } \\
\text { citizenship level/ }\end{array}$} & \multirow{2}{*}{$\begin{array}{l}\text { High } \\
\text { digital citizenship level/ }\end{array}$} & \multirow{3}{*}{$\begin{array}{l}\text { Very high } \\
\text { digital citizenship } \\
\text { level/ Very } \\
\text { favorable }\end{array}$} \\
\hline & & & & \\
\hline Very unfavorable & & & favorable & \\
\hline terrorism & $\begin{array}{l}\text { Unfavorable attitudes } \\
\text { toward terrorism }\end{array}$ & $\begin{array}{l}\text { Neutral attitudes } \\
\text { toward terrorism }\end{array}$ & $\begin{array}{l}\text { attitudes } \\
\text { terrorism }\end{array}$ & $\begin{array}{l}\text { attitudes toward } \\
\text { terrorism }\end{array}$ \\
\hline
\end{tabular}

\section{Findings and Discussion}

The analysis of the data was performed using descriptive statistics. Descriptive measures including means and standard deviations for digital citizenship domains and attitudes toward terrorism. Descriptive measures were computed to answer the questions of the study; these descriptive statistical measures were presented for classifying variable (Gender, Types of the study). Results according to questions of the study were presented as follow:

6.1 Results of the first research question: What is the digital citizenship level of Ma'an secondary school students?

One sample t-test with $(D F=185)$ was used to determine the digital citizenship level of Ma'an 
secondary school students at the crucial score of upper bound of digital citizenship degree (see Table 4):

Table 4. Results of one sample t-test for participants' levels of digital citizenship

\begin{tabular}{lllllll}
\hline Domains & Mean & SD & Rank & Crucial Score & T value & Sig \\
\hline Etiquette & 3.59 & 0.86 & & & 3.002 & .003 \\
Responsibility & 3.89 & 0.74 & & & 9.010 & .000 \\
Wellbeing/Health & 3.65 & 0.89 & High & 3.40 & 3.831 & .000 \\
Commerce & 3.96 & 0.81 & & & 9.417 & .000 \\
Security & 4.08 & 0.86 & & & 10.791 & .000 \\
Digital Citizenship & 3.84 & 0.57 & & 10.468 & .000 \\
\hline
\end{tabular}

One sample t-test revealed significant differences at $\alpha \leq 0.05$ between the means of digital citizenship and its domains at the crucial score (3.40) which represents the upper bound of high degree. Thus, the digital citizenship levels of secondary school students in Ma'an directorate and its domains were at a high level. Such high level of digital citizenship might be attributed the educational system and the social environment for the students, where the educational and social systems in Jordan focuses on enhancing students' citizenship's value. In addition, some researchers pointed to the role of Islamic education on enhancing students' citizenship's value in the Islamic world in general and in Jordan in particular (Sroor \& Al-Azzam, 2012). The results aligned with the results of similar studies (Nordin, et al, 2016; Xu, Yang, MacLeod, \& Zhu, 2018).

6.2 Results of Q2: Do males and females of secondary school students in Ma'an Directorate differ on their level of digital citizenship and its domains?

The analyses of two sample t-test with $(D F=184)$ was used to determine the Male/Female secondary students' differences of their levels of digital citizenship and its domains as shown in Table 5.

Table 5. Results of two sample t-test for digital citizenship levels by gender

\begin{tabular}{llllllll}
\hline \multirow{2}{*}{ Domains } & \multicolumn{2}{l}{ Male. $\mathrm{n}=83$} & \multicolumn{2}{c}{ Female. $\mathrm{n}=103$} & t- value & Sig \\
\cline { 2 - 6 } & Mean & SD & Mean & SD & & \\
\hline Etiquette & 3.53 & 0.94 & 3.64 & 0.79 & 0.845 & .399 \\
Responsibility & 3.82 & 0.85 & 3.94 & 0.63 & 1.108 & .269 \\
Wellbeing/Health & 3.76 & 0.91 & 3.56 & 0.85 & 1.587 & .114 \\
Commerce & 3.99 & 0.80 & 3.94 & 0.83 & 0.472 & .637 \\
Security & 4.01 & 0.88 & 4.14 & 0.84 & 1.011 & .314 \\
Digital Citizenship & 3.82 & 0.65 & 3.85 & 0.50 & 0.295 & .768 \\
\hline
\end{tabular}

Two sample t-tests revealed no significant differences at $\alpha \leq 0.05$ between the means of 
males/females at the digital citizenship and its domains. Thus, males and females of secondary students in Ma'an directorate do not differ on their digital citizenship levels and its domains. The insignificant differences between the male and female students in their perceptions of their level of digital citizenship was expected since the female and male students receive the same education and they live in the same social environment.

6.3 Results of Q3: Do secondary school students in Ma'an Directorate differ on their level of digital citizenship and its domains according to their type of study?

To answer the third question, means and standard deviations were computed to examine the differences of digital citizenship levels according to terms of study as shown in Table 6.

Table 6. Digital citizenship means and standard deviations by the type of study

\begin{tabular}{lllllll}
\hline \multirow{2}{*}{ Domains } & \multicolumn{2}{l}{ Science. N=70 } & \multicolumn{2}{c}{ Art. N=68 } & \multicolumn{2}{c}{ Vocational. N=48 } \\
\cline { 2 - 7 } & Mean & SD & Mean & SD & Mean & SD \\
\hline Etiquette & 3.66 & 0.85 & 3.65 & 0.84 & 3.40 & 0.90 \\
Responsibility & 4.98 & 0.66 & 3.27 & 0.71 & 3.74 & 0.84 \\
Wellbeing/Health & 3.69 & 0.93 & 3.54 & 0.89 & 3.74 & 0.81 \\
Commerce & 4.15 & 0.82 & 3.87 & 0.76 & 3.81 & 0.83 \\
Security & 4.11 & 0.95 & 4.04 & 0.85 & 4.08 & 0.73 \\
Digital Citizenship & 3.93 & 0.57 & 3.79 & 0.54 & 3.75 & 0.59 \\
\hline
\end{tabular}

Table 6 shows observable differences between the means of students' perceptions of their levels of digital citizenship according to type of study. One way ANOVA conducted to examine the observed differences as shown in Table 7.

Table 7. One way ANOVA summery- students' perceptions of their levels of digital citizenship for type of study

\begin{tabular}{|c|c|c|c|c|c|c|}
\hline Source of Variance & & Sum of Squares & $\mathrm{DF}$ & Mean Square & $\mathrm{F}$ & Sig. \\
\hline \multirow{2}{*}{ Etiquette } & Between Groups & 2.266 & 2 & 1.133 & 1.536 & .218 \\
\hline & Within Groups & 134.963 & 183 & 0.738 & & \\
\hline \multirow{2}{*}{ Responsibility } & Between Groups & 2.584 & 2 & 1.292 & 2.427 & .091 \\
\hline & Within Groups & 97.462 & 183 & .532 & & \\
\hline \multirow{2}{*}{ Wellbeing/Health } & Between Groups & 1.365 & 2 & 0.682 & 0.869 & .421 \\
\hline & Within Groups & 143.687 & 183 & 0.785 & & \\
\hline \multirow{2}{*}{ Commerce } & Between Groups & 4.256 & 2 & 2.128 & 3.309 & .039 \\
\hline & Within Groups & 117.677 & 183 & 0.643 & & \\
\hline \multirow{2}{*}{ Security } & Between Groups & 0.149 & 2 & 0.074 & 0.100 & .905 \\
\hline & Within Groups & 136.028 & 183 & 0.743 & & \\
\hline \multirow{2}{*}{ Digital Citizenship } & Between Groups & 1.137 & 2 & 0.569 & 1.777 & .172 \\
\hline & Within Groups & 58.565 & 183 & 0.320 & & \\
\hline
\end{tabular}


Results of ANOVA revealed no significant differences at $\alpha \leq 0.05$ between means of students' responses to the digital citizenship levels according to the type of study at domains (etiquette, responsibility, wellbeing/health, security, and digital citizenship), while there were significant differences between means of students' responses to commerce domain based on their type of study. Thus, secondary school students in Ma'an directorate do not differ on their level of digital citizenship and its domains according to their term of study, except commerce domain. Scheffe's Post multiple comparisons conducted to assure those differences as shown in Table 8.

Table 8. Results of Scheffe's Multiple Comparisons One way ANOVA for students' perceptions of their levels of digital citizenship for type of study

\begin{tabular}{llllll} 
Dependent Variable & (I) Term & (J) Term & $\begin{array}{l}\text { Mean Difference } \\
\text { (I-J) }\end{array}$ & Std. Error & Sig. \\
& & & & & \\
\hline Commerce & Science & Art & .27983 & .13654 & .125 \\
& & Vocational & .34683 & .15028 & .072 \\
& Art & Science & -.27983 & .13654 & .125 \\
& & Vocational & .06699 & .15117 & .907 \\
\hline
\end{tabular}

* The mean difference is significant at the .05 level.

Post comparisons showed that students in science major with the mean of $=4.15$ and standard deviations of .82 were higher than students' means in both Art and Vocational but without statistical significance. Thus they did not differ in their digital citizenship in at the domain of commerce.

The insignificant differences in students' perceptions of their level of digital citizenship might ne attributed to the fact the students live in the same social environment. In addition, the Jordanian educational system offer the same set of basic courses in religion, language, and citizenship to the students in all type of study i.e., science, art, vocational.

6.4 Results of Q4: What are the Ma'an secondary school students' attitudes toward electronic terrorism?

Items in the attitudes scale with negative statement were reversed when using SPSS, therefore all the instrument items pointing to positive attitudes toward electronic terrorism. The analysis of one sample t-test with $(D F=186)$ was used to determine students' attitudes toward electronic terrorism. The results showed that the Ma'an secondary school students had an unfavorable attitudes toward electronic terrorism $(M=1.72, S D=0.42)$, when comparing the mean with the crucial score of lower bound of low attitudes toward electronic terrorism $=1.81$.

One sample t-test revealed significant differences at $\alpha \leq 0.05$ between the mean of attitudes toward electronic terrorism at the crucial score (1.81) which represents the lower bound of low level, was the computed $\mathrm{t}=3.649$. Thus, the secondary school students in Ma'an Directorate had very unfavorable attitudes toward electronic terrorism. Such unfavorable attitudes toward electronic terrorism might be attributed the educational system and the social environment for 


\section{Macrothink}

the students.

6.5 Results of Q5: Is there a relationship between digital citizenship and attitudes toward electronic terrorism among secondary school students?

To answer the fifth question, means and standard deviations were computed and both digital citizenship and electronic terrorism were ranked. Figurel showed digital citizenship and electronic terrorism as distribution ranks.

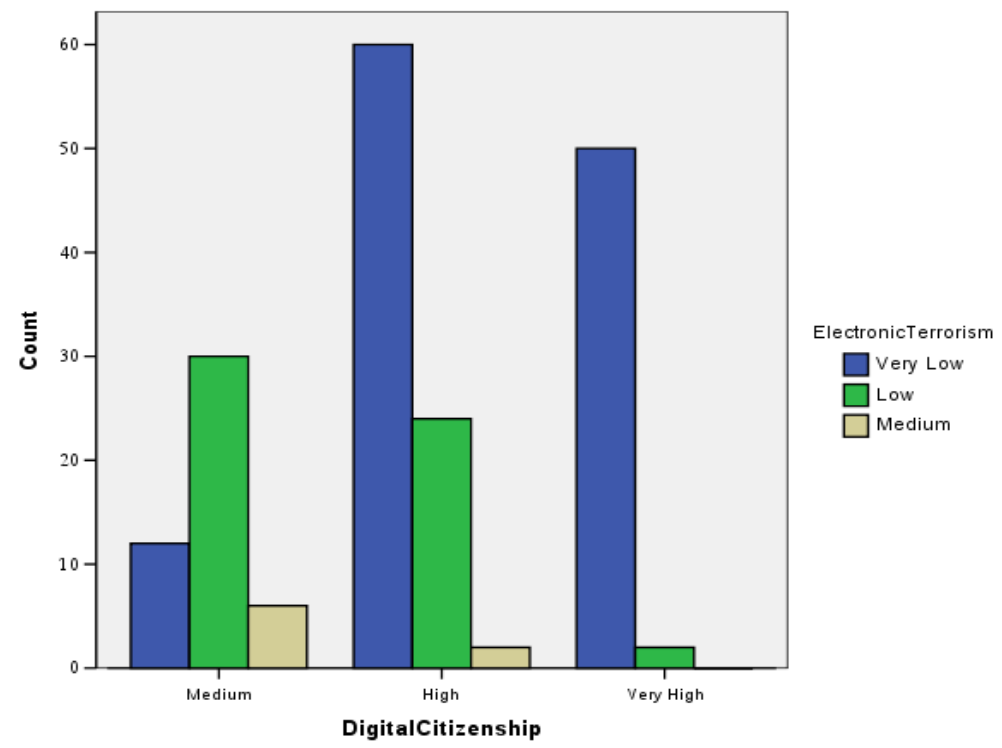

Figure 1. digital citizenship and electronic terrorism as distribution ranks

As shown in Figure 1, students with high and very high levels of digital citizenship have very unfavorable attitudes toward electronic terrorism, while students with medium level of digital citizenship have unfavorable attitudes toward electronic terrorism as shown in Table 9 of crosstabs.

Table 9. Electronic Terrorism * Digital Citizenship Cross tabulation

\begin{tabular}{|c|c|c|c|c|c|c|c|}
\hline \multirow{2}{*}{ Count } & & & & \multicolumn{3}{|c|}{ Digital Citizenship } & \multirow{2}{*}{ Tota } \\
\hline & & & & Medium & High & Very High & \\
\hline \multirow{3}{*}{$\begin{array}{l}\text { Attitudes } \\
\text { terrorism }\end{array}$} & toward & electronic & Very Low & 12 & 60 & 50 & 122 \\
\hline & & & Low & 30 & 24 & 2 & 56 \\
\hline & & & Medium & 6 & 2 & 0 & 8 \\
\hline \multicolumn{4}{|l|}{ Total } & 48 & 86 & 52 & 186 \\
\hline
\end{tabular}

Linear regression was used to determine the relationship between digital citizenship and electronic terrorism based on the assumption: students with very high digital citizenship will have very unfavorable attitudes toward electronic terrorism. Model of regression summary showed that $\mathrm{R}=0.715$, Adjusted $\mathrm{R}$ square $=0.508$ and ANOVA showed significant statistics at $\alpha \leq 0.05$, the $F$ has a value of 191.933 as shown in Table 10 , which indicates the statistical significance of the regression model: 


\section{Macrothink}

International Journal of Learning and Development

ISSN 2164-4063 2019, Vol. 9, No. 1

Table 10. Results of ANOVA(b)

\begin{tabular}{lllllll}
\hline Model & & Sum of Squares & df & Mean Square & F & Sig. \\
\hline 1 & Regression & 16.759 & 1 & 16.759 & 191.933 & .000 (a) \\
& Residual & 16.067 & 184 & .087 & & \\
& Total & 32.826 & 185 & & & \\
& & & & & &
\end{tabular}

a Predictors: (Constant): Digital Citizenship.

b Dependent Variable: Electronic Terrorism.

To predict attitudes toward electronic terrorism from digital citizenship, as well as determine whether attitudes toward electronic terrorism contribute statistically significant to the model, coefficients were used, as shown below.

Table 11. Coefficients (b)

\begin{tabular}{lllllll}
\hline \multirow{2}{*}{ Model } & & \multicolumn{2}{l}{ Unstandardized Coefficients } & $\begin{array}{l}\text { Standardized } \\
\text { Coefficients }\end{array}$ & \multirow{2}{*}{ Sig. } \\
\cline { 3 - 5 } & & $\mathrm{B}$ & Std. Error & \multicolumn{2}{l}{ Beta } & \\
\hline 1 & (Constant) & 3.748 & .148 & & 25.276 & .000 \\
& Digital Citizenship & -.530 & .038 & -.715 & -13.854 & .000 \\
\hline
\end{tabular}

a Dependent Variable: Electronic Terrorism.

Table 11 shows the regression equation coefficients. The scatter plot demonstrates the calculation of covariance (Figure 2).

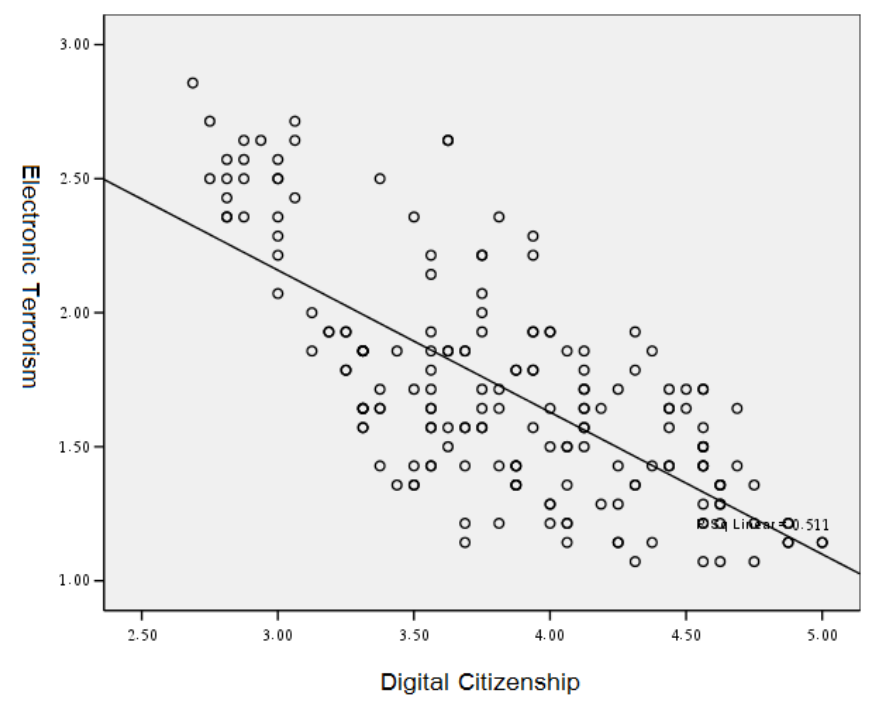

Figure 2. Scatterplot of the calculation of covariance

\section{Conclusion}

The study revealed that Ma'an secondary school students have a high level of digital citizenship level and very unfavorable attitudes toward electronic terrorism, while the high digital 
citizenship will have a great role to play in standing against electronic terrorism. It is very obvious that terrorism is not of human being nature, in fact, more teenagers have feeling of responsibility toward their country and feel safe with no outside interfering they will feel more with others, thus, this study turn the light on youths' behaviors and values more globally, not only within their own environment.

\section{References}

Abdullah, K., Sukma, R., \& Musa, M. (2012). Perception and attitudes toward terrorism in a Muslim majority country. Asian Social Science, 8(4), 77. https://doi.org/10.5539/ass.v8n4p77

Al-Said, S. (2017). Digital citizenship and its role in the face of cyber terrorism. Scientific paper presented to the conference to confront intellectual extremism (reality and hope) Ministry of Awqaf - State of Kuwait [Arabic]

Al-Sanad, A. (na). Means of electronic terrorism: Ruling on Islam and ways to face it. Retrieved from http://www.assakina.com/files/books/book8.pdf [Arabic]

Atia, A. (2014). The role of modern mechanisms to reduce the newly created crimes of electronic terrorism and ways to confront it. Paper presented at Crimes created in the light of regional and international changes scientific meeting. Retrieved from https://repository.nauss.edu.sa[Arabic]

Gasaymeh, A. (2018). A Study of Undergraduate Students' Use of Information and Communication Technology (ICT) and the Factors Affecting their Use: A Developing Country Perspective. EURASIA Journal of Mathematics, Science and Technology Education, 14(5), 1731-1746. https://doi.org/10.29333/ejmste/85118

Gasaymeh, A. M. M., Ma'an, J., Al-Taweel, A. M., Al-Moghrabi, K. G., \& Al-Ghonmein, A. M. (2017). University Students' Perceptions of the Use of Digital Technologies in their Formal Learning: A Developing Country Perspective.

Jwaifell, M., Al-Shalabi, H., Andraws, S., Awajan, A., \& Alrabea, A. I. (2013). The intensity of social networks group use among the students of Jordanian universities. Global Journal of Computer Science and Technology, 13(2).

Li, Q. (2006). Cyberbullying in schools: A research of gender differences. School psychology international, 27(2), 157-170. https://doi.org/10.1177/0143034306064547

Murugesan, S. (2007). Understanding Web 2.0. IT professional, 9(4). https://doi.org/10.1109/MITP.2007.78

Nordin, M. S., Ahmad, T. B. T., Zubairi, A. M., Ismail, N. A. H., Rahman, A. H. A., Trayek, F. A., \& Ibrahim, M. B. (2016). Psychometric properties of a digital citizenship questionnaire. International Education Studies, 9(3), 71. https://doi.org/10.5539/ies.v9n3p71

Oxley, C. (2010, January). Digital citizenship: Developing an ethical and responsible online culture. In International Association of School Librarianship. Selected Papers from the... Annual Conference (p. 1). International Association of School Librarianship. 


\section{Macrothink}

International Journal of Learning and Development

ISSN 2164-4063 2019, Vol. 9, No. 1

Pollitt, M. M. (1998). Cyberterrorism—fact or fancy? Computer Fraud \& Security, 1998(2), 8-10. https://doi.org/10.1016/S1361-3723(00)87009-8

Ribble, M. (2011). Digital citizenship in schools. International Society for Technology in Education. Retrieved from https://www.iste.org/docs/excerpts/DIGCI2-excerpt.pdf

Ribble, M. S., Bailey, G. D., \& Ross, T. W. (2004). Digital citizenship: Addressing appropriate technology behavior. Learning \& Leading with technology, 32(1), 6.

Smith, P. K., Mahdavi, J., Carvalho, M., Fisher, S., Russell, S., \& Tippett, N. (2008). Cyberbullying: Its nature and impact in secondary school pupils. Journal of child psychology and psychiatry, 49(4), 376-385. https://doi.org/10.1111/j.1469-7610.2007.01846.x

Sroor, F., \& Al-Azzam, M. (2012). The Role of Developing Islamic Education Methods to Increase the Citizenship's Values in the Primary Schools according to Teacher's point of View (in Third Irbid Educational Site). Dirasat: Educational Sciences, 39(2).

Tapscott, D. (2009). Grown up digital (Vol. 361). New York: McGraw Hill.

Xu, S., Yang, H. H., MacLeod, J., \& Zhu, S. (2018). Social media competence and digital citizenship among college students. Convergence: The International Journal of Research into nNew Media Technologies, 1-18, https://doi.org/10.1177/1354856517751390

\section{Copyright Disclaimer}

Copyright for this article is retained by the author(s), with first publication rights granted to the journal.

This is an open-access article distributed under the terms and conditions of the Creative Commons Attribution license (http://creativecommons.org/licenses/by/4.0/). 